\title{
Dental care necessity at productive age in Cilayung Village, Jatinangor Districts Sumedang Regency
}

\author{
Granidya Rosa Atlantika*, Anne Agustina Suwargiani*, Sri Susilawati* \\ *Department of Dental Public Health Faculty of Dentistry Universitas Padjadjaran, Indonesia
}

\begin{abstract}
Introduction: The need of dental care is defined as a collection of dental and oral treatment in which according to dental personnel should be obtained by a certain period in order to achieve good dental health status. According to WHO, the productive age is the age group between $35-44$ and is considered as the standard age for checking the adult oral health condition. The purpose of this research is to obtain the necessity of oral health data at productive age in Cilayung village. Method: The research method was descriptive with cluster sampling technique. Samples of 80 respondents were obtained by pathfinder surveys technique. The necessity of dental care was assessed using WHO oral health surveys and the dental condition of respondents were checked using mouth mirror. Result: The results shows that the highest number of caries prevention is many as 80 people $(100 \%)$ and the need for one surface treatment as many as 75 people (93.75\%). Conclusion: The research concluded that the people in Cilayung village is in high need of caries and surface treatment.
\end{abstract}

Keywords: Oral health care necessity, productive age, Cilayung village

P-ISSN 1979-0201, e-ISSN 2549-6212 Available from:http://jurnal.unpad.ac.id/pjd/index

DOI:http://dx.doi.org/10.24198/pjd.vol29no2.12307

Submission: Feb 2017 Publishing: July 2017

\section{INTRODUCTION}

Dental caries is the most common dental disease in Indonesia and can affect people from every level of society. ${ }^{1}$ The results of Riskesdas ${ }^{2}$ show the highest proportion of people at 35-44 years of productive age who have dental and mouth problems (based on perceived need) is $30.5 \%$, while the proportion based on expressed needs is $10.3 \% .^{2}$

Based on Riskesdas data and indications of normative dental care needs at the 35-44 year old people is still high but the ability to get dental care at that age is still low due to busy work, time, cost, and attitude. ${ }^{3}$ Dental and oral health problems occuring at the age of $35-44$ years old is indicated by the prevalence of the highest DMFT index. $^{4}$

Component $D$ (caries) reflects the need for dental care (normative needs), the high number of component $D$ (caries) shows the increasing normative needs. Component $F$ shows expressed needs. Dental care needs are defined as a collection of dental and oral care which according

Corresponding author: Granidya Rosa Atlantika Department of Dental Public Health. Faculty of Dentistry Univ. Padjadjaran Jl. Sekeloa Selatan No. 1 Bandung, West Java-Indonesia, Phone/Fax: +6222-2504985, email: granidya@yahoo.com 
to dental and medical personnel must be obtained by a person in a certain period of time in order to achieve good dental health status. The dental and oral health of the patient is strongly influenced by personal beliefs, cultural background, social factors, education, and environment. ${ }^{5}$

The largest population in Cilayung village is a productive age population. ${ }^{6}$ In Cilayung village there is no hospital or practice place of doctors or dentists. ${ }^{7}$ Indonesians have dental and mouth problems in the last 12 months recorded an average of $25.9 \% .31 .1 \%$ of them received treatment from dental personnel (dentists, dental nurses, or dentists specialists), while another $68.9 \%$ were not treated. ${ }^{2}$

\section{METHODS}

This research type was descriptive research by doing survey in Cilayung Village. The population taken in this study was the productive age society in Cilayung village aged of 35-44 years based on WHO Oral Health Surveys 2013. The sampling technique used is cluster sampling technique with pathfinder surveys method, which aim to cover the major population groups who generally suffer from different diseases in terms of their type and severity. This method can also be used to estimate the number of subjects for each age group in each location. ${ }^{8}$

Based on the pathfinder surveys sampling method, the number of subjects to be examined in each age group index ranges from 25-50 for each region, depending on the prevalence and severity of an area. A minimum sample of 80 people with a ratio of 40 men and 40 women in 2 RW namely RW 002 and RW 009 Cilayung are willing to follow this research and these numbers are obtained through pathfinders' survey. The tools used in this study include excavator, glass mouth, mask and gloves, mouth rinse, $70 \%$ alcohol, tissue/cotton, flashlight, stationery, check forms from WHO and informed consent.

The examination is performed by one person who has underwent the stages of the calibration procedure. The examiner records the identity of the examining subject on the examination form, such as name, age, sex, occupation, address. The informed consent will then be given to the subject whether they approve or disapprove of the examination. the subject of the study who agreed, they were asked to sit on the chair for having dental examination to determine the dental health status. The researcher will perform systematic inspection of the subject's teeth, the assessment was started from the upper right region, the upper left region, the lower left region, and lastly the lower right region. The examination result will then be recorded on the inspection form and on which there is two check boxes for each jaw. The top of the box is used to fill the subject gear status and the bottom box is used to fill dental care needs. The box is filled with the code located to the right of the box.

In the upper box is filled with the patient's tooth status code, which is the code of 0 is for healthy teeth, code 1 is for dental holes/caries, code 2 is for caries disarray, code 3 is for untreated blowing, code 4 is for tooth removed or missing Due to caries, code 5 is for teeth removed or lost for other reasons, code 6 is for fissure sealant, code 7 is for abutment bridges and special crown/ veneer/implant, code 8 is for non-eruptive teeth, code $\mathrm{T}$ for trauma (fracture), code 9 is for teeth not including the above criteria. In the bottom box filled with the patient's dental needs code, the code of dental care needs such as P code for the prevention and treatment of caries,

$F$ codes is for fissure sealant, code 1 is for one surface coat, code 2 is for patching of two or more surfaces, codes 3 is for prostheses/ bridges, code 4 is for veneers/coatings (may be recommended for aesthetic purposes), code 5 is for pulp treatment And restoration, code 6 is for retraction. Data collected then processed and presented in tabular form.

\section{RESULTS}

The results accumulated based on the research on dental care needs at productive age range of 35- 44 years old conducted in Cilayung Village Jatinangor District Sumedang is presented in Table 1.

In Table 1 it can be seen that the respondents who are residents of Cilayung Village Jatinangor are 80 respondents. Most of the respondents have job as a housewives that is 28 respondents (35\%).

Table 2 shows the last education level of 80 respondents from Cilayung Village Jatinangor. 
Table 1. Frequence distribution of the respondents occupation

\begin{tabular}{lcc}
\hline Occupation & Frequency & Percentage \\
\hline House wife- & 28 & 35 \\
Enterpreneur & 14 & 17.50 \\
Civil employee & 9 & 11.25 \\
Private employee & 8 & 10 \\
Village officials & 5 & 6.25 \\
Unemployment & 5 & 6.25 \\
Construction laborers & 3 & 3.75 \\
Security personnel, leanliness & 2 & 2.50 \\
andEnvironmentalorderinunpad & & \\
Booth maker & 2 & 2.50 \\
Driver & 1 & 1.25 \\
School guard & 1 & 1.25 \\
Laborers & 1 & 1.25 \\
Army & 1 & 1.25 \\
\hline Total & 80 & 100 \\
\hline
\end{tabular}

Tabel 2. Frequnce distribution of respondents education level

\begin{tabular}{lcc}
\hline Education & Frequency & Percentage \\
\hline Unschooling & 1 & 1.25 \\
Elementary & 26 & 32.50 \\
Junior high school & 13 & 16.25 \\
Senior high school & 28 & 35 \\
College & 12 & 15 \\
\hline Total & $\mathbf{8 0}$ & $\mathbf{1 0 0}$ \\
\hline
\end{tabular}

Tabel 3.Dental health status at productive age based on number of respondents

\begin{tabular}{|c|c|c|c|}
\hline Code & Status & $\begin{array}{c}\text { Total } \\
\text { respondent }\end{array}$ & Percentage \\
\hline 0 & Healthy teeth & 79 & 98.75 \\
\hline 1 & Caries & 79 & 98.75 \\
\hline 2 & Filling plus caries & 5 & 6.25 \\
\hline 3 & Filling without caries & 2 & 2.50 \\
\hline 4 & $\begin{array}{l}\text { Extracted teeth due to } \\
\text { caries }\end{array}$ & 53 & 66.25 \\
\hline 5 & $\begin{array}{l}\text { Extracted teeth due to } \\
\text { another reason }\end{array}$ & 12 & 15 \\
\hline 6 & Fissure sealant & 0 & 0 \\
\hline 7 & $\begin{array}{l}\text { Denture, abutment } \\
\text { tooth, crown, veneer }\end{array}$ & 1 & 1.25 \\
\hline 8 & Unerupted tooth & 14 & 17.05 \\
\hline $\mathrm{T}$ & Trauma/fracture & 3 & 3.75 \\
\hline 9 & None of the above Total & II & 13.75 \\
\hline
\end{tabular}

Most of the respondents had a senior high school education (SMA) that is 28 respondents (35\%).
Table 4.Dental health status at a productive age based on number of teeth

\begin{tabular}{clcc}
\hline Code & Status & $\begin{array}{c}\text { Total number } \\
\text { of teeth }\end{array}$ & Percentage \\
\hline 0 & Healthy teeth & 1450 & 56.64 \\
1 & Caries & 787 & 30.74 \\
2 & Filling plus caries & 6 & 0.23 \\
3 & Filling without caries & 6 & 0.23 \\
4 & Extracted teeth due & 198 & 7.73 \\
& to caries & & \\
5 & Extracted teeth due & 15 & 0.58 \\
6 & to another reason & & \\
7 & Fissure sealant & 0 & 0 \\
7 & Denture, abutment & 1 & 0.03 \\
8 & tooth, crown, veneer & & \\
$\mathrm{T}$ & Tnerupted tooth & 34 & 1.32 \\
9 & Trauma/fracture & 3 & 0.11 \\
\hline & None of the above & 60 & 2.34 \\
\hline
\end{tabular}

Table 5. Dental care requirement at productive age based on the number of respondents

\begin{tabular}{clcc}
\hline Code & \multicolumn{1}{c}{ Treatment } & Total responden & Perscentage \\
\hline 0 & None & 0 & 0 \\
$\mathrm{P}$ & Caries prevention & 80 & 100 \\
& Fissure sealant & 11 & 13.75 \\
1 & One surface filling & 75 & 93.75 \\
2 & Two surfaces filling & 47 & 58.75 \\
3 & Denture/crown and & 59 & 73.75 \\
& bridge & & \\
4 & Veneer & 5 & 6.25 \\
5 & Treatment and res- & 11 & 13.75 \\
& toration & & \\
6 & Tooth extraction & 51 & 63.75 \\
\hline
\end{tabular}

Dental health status of 80 respondents showed that 79 respondents $(98.75 \%$ ) had healthy teeth in their oral cavity and 79 respondents (98.75\%) had dental caries (Table 3). Table 4 exhibits that the dental health status of 80 respondents showing most of the respondents has healthy dental status with the amount of 1450 teeth (56.64\%).

Table 5 shows that all of 80 respondents indicated needing of caries prevention care is at $100 \%$. Table 6 shows the result that dental care needs of 80 respondents indicated that productive age in Cilayung need dental care based on the number of teeth requiring caries prevention care were 1483 teeth $(57.89 \%)$. 
Table 6. Dental care requirements at productive age based on number of teeth

\begin{tabular}{clcc}
\hline Code & Treatment & $\begin{array}{c}\text { Total number } \\
\text { of teeth }\end{array}$ & Percentage \\
\hline 0 & None & 0 & 0 \\
P & Caries prevention & 1482 & 57.89 \\
F & Fissure sealant & 31 & 1.21 \\
1 & One surface filling & 509 & 19.88 \\
2 & Two surfaces filling & 122 & 4.76 \\
3 & Denture/crown & 211 & 8.24 \\
4 & and bridge & & \\
\multirow{2}{*}{5} & Veneer & 10 & 0.39 \\
& Treatment and resto- & 13 & 0.50 \\
6 & Tooth extraction & 182 & 7.10 \\
\hline & Total & 2560 & 100 \\
\hline
\end{tabular}

\section{DISCUSSION}

The depiction of dental care needs at productive age in Cilayung based on Table 3 shows that dental health status of productive age population in Cilayung is 79 respondents $(98.75 \%)$ and Table 4 shows that 1450 respondents $(56.64 \%)$ have healthy teeth. The results of this study indicate that the number of healthy teeth is very high, but still visible signs of early caries lesions of spots or white spots, discoloration or rough stains that can lead to more severe caries. It is important to be noted to prevent oral dan dental disease.

Table 5 shows the results of 80 respondents (100\%) requiring caries prevention care. Maintaining oral hygiene is the best way to prevent the occurrence of mouth disease, such as caries and gingivitis.

Table 2 shows from 80 respondents who were examined, as many as 28 respondents (35\%) graduated from high school. Survey conducted by Maulana', said that people who have a high level of education will have a better knowledge and a good attitude regarding health in general. Hence, it will affect their behavior towards healthy living and can maintain a good dental health. Generally, people with higher education level have higher economic status so helps in taking care of dental hygiene as recommended by dentist. Previous research conducted by Setyowati ${ }^{10}$ di Napier suggests that there is a correlation between socioeconomic factors and the status of tooth loss. ${ }^{9}$ According to Blum's theory in Kiswaluyo ${ }^{11}$ a person's dental health status can be affected by one of them is the level of education, where the higher level of education The more knowledge will be gained. ${ }^{11}$

Table 3 shows that the highest dental health status of 35-44 years old was the respondents who had carious teeth in the oral cavity of 79 respondents $(98.75 \%)$ and Table 4 shows that dental health status based on the number of teeth examined was 787 teeth (30.74\%) who had caries. Based on Benedicto's ${ }^{12}$ research in Brazil that caries and periodontal diseases are major health problems affecting most of the adult population over 35 to 40 years. ${ }^{9}$ This is reinforced by research in the Jakarta Public Health Center conducted by Indirawati and Lannywati ${ }^{13}$ in 2007 which stated that the increase dental caries cannot be separated from the factors that cause dental caries, namely direct and indirect factors. Age is an indirect factor that causes an increase in dental caries, with 35 years of age as much as $70 \% .^{13}$

The absence of medical prectices including dentists in Cilayung and the distance to the nearest Puskesmas has a direct affect to their dental health status and the dire need of proper care and treatment. The location of Puskesmas located in the center of Jatinangor, allows the community to easily conduct routine visits to the Puskesmas, so that cases of dental caries in the community can be handled quickly, resulting in the number of patients with an indication of deprivation is reduced. Therefore, the number of fillings is greater than the number of tooth extractions. Research conducted by Kiswaluyo ${ }^{11}$ in 2012 concludes that proximity or distance of health services with shelter is a major factor to consumer demand in the utilization of health services.

\section{CONCLUSION}

The research concluded that the people in Cilayung village is in high need of caries and surface treatment.

\section{REFERENCES}

1. Rosidi A, Siti H, Eka A. Hubungan antara konsumsi makanan kariogenik dengan kejadian karies gigi pada anak SDN 1 Gogo dalem Kecamatan Bringin Kabupaten Semarang. [cited 2016 Oct ]. Available online from: jurnal.unimus.ac.id. 2013. 
2. Riset Kesehatan Dasar. Dinas Kesehatan Republik Indonesia. [cited 2016 Sep ]. Available online from: www.depkes.go.id. 2013.

3. Watch D. Productivity Loses From Dental Problems. Aust Dent J 2012;57:393-7.

4. Kumar G, Ranjan MT, Dileep CL, Megha T, Shitanshu M, Pallavi S. Assessment of oral health status and treatment needs of shantal tribes of dhanbad district jharkand. J Int Soc Prev and Comm Dent 2016;6(4):338-43.

5. Pne CM. Community Oral Health. London: Wright. 2003. P. 39-41,43-4.

6. Ramraj C, Amir A, Laura D, Vahid R, Carlos Q et al. Dental treatment needs in the Canadian population: analysis of a nationwide crosssectional survey. BMC oral health 2012;12:46.

7. Data Profil Desa Cilayung Kecamatan Jatinangor Kabupaten Sumedang. 2016.

8. World Health Organization. Oral Health Surveys Basic Methods. $5^{\text {th }}$ ed. France. 2013. P. 15,19-21,43-7,74.

9. Maulana E, Rosihan A, Farida H. Faktor yang mempengaruhi kehilangan gigi pada usia 35-44 tahun di Kecamatan Juai Kabupaten balangan tahun2014 tinjauan terhadap pengetahuan dan sosial ekonomi. Dentino J Kedokteran Gigi 2016;1(1):98-103.

10. Setyowati. Hubungan faktor sosial ekonomi dengan status kehilangan gigi pada remaja. Available from:http//respitatory.unhas.ac.id.

11. Kiswaluyo. Pelayanan kesehatan gigi di Puskesmas (Studi kasus di Puskesmas Sumbersari). Stomatognatic. JKG Unej 2013;10(1):12-6.

12. Benedicto. Faktor yang mempengaruhi kehilangan gigi pada usia 35-44 Tahun di Kecamatan Juan Kabupaten Balangan Tahun 2014. In: Maulana E, Rosihan A, Fadida H. Tinjauan pengetahuan dan sosial ekonomi. Dentino Jurnal Kedokteran Gigi 2014;1(1):98103.

13. Sintawati FX, Indirawati T. Faktor-faktor yang mempengaruhi kebersihan gigi dan mulut masyarakat DKI Jakarta tahun 2007. J Ekologi Kesehatan 2009;8(1):860-73.

14. Indirawati Tjahja N, Lannywati G. Status kesehatan gigi dan mulut ditinjau dari faktor individu pengunjung Puskesmas DKI Jakarta Tahun 2007. Buletin Penelitian Kesehatan 2010;38(2):52-66.

15. Depkes RI. Keputusan Menteri RI No. 128/ Menkes/SK/II/2004 Tentang Kebijakan Dasar Pusat Kesehatan Masyarakat. Jakarta: Departemen Kesehatan Republik Indonesia. In Stomatognatic (J.K.G. Unej) 2004;10(1).2013: 12-16. 